\title{
FRYING OIL QUALITY IN FAST FOOD RESTAURANTS IN EAST COAST OF MALAYSIA: A PRELIMINARY SURVEY
}

\begin{abstract}
NUR HAQIM ISMAIL*; AZMIL HAIZAM AHMAD TARMIZI*; NORAZURA AILA MOHD HASSIM*; SIVARUBY KANAGARATNAM* and NOOR LIDA HABI MAT DIAN*
\end{abstract}

\begin{abstract}
Fresh, in-use regardless the days of frying and discarded oils were collected from fast food restaurants in Kuala Terengganu, Terengganu, Malaysia to investigate the quality of the frying oil used in the commercial frying industries. The fresh oils used in these restaurants were palm olein and/or palm oil. Oxidative stability index (OSI), smoke point, colour, free fatty acid (FFA), polar compound, peroxide value (PV) and $\rho$-anisidine value $(\rho-A V)$ were evaluated. The fresh oils showed quality that is within specification of standards and references. The in-use oils showed a high degree of deterioration by having a lower OSI, smoke point, and darker colour. High levels of FFA showed that $42.9 \%$ of in-use oils and $100 \%$ of discarded oils had exceeded the maximum limit of 1\%. Polar compound of $42.9 \%$ of the in-use oils and $50 \%$ of the discarded oils had exceeded the maximum limit (>27\%). As high as $81 \%$ of the in-use oils and $75 \%$ of the discarded oil collected having $\rho-A V$ of more than 10 which suggests that inspection by the local authority should be carried out to monitor the quality of the cooking oil used in the fast food restaurants.
\end{abstract}

Keywords: fast food restaurants, frying oil, oil quality.

Received: 25 February 2020; Accepted: 9 July 2020; Published online: 22 September 2020.

\section{INTRODUCTION}

Fried food products are popular nowadays with good acceptance and demand globally. Deep frying is a cooking method whereby the food is immersed in hot oil or fat. Deep frying method used for the production of fried food products has been used for decades and the preferable method of cooking nowadays as it is simple, fast and convenient providing distinctively good sensory properties (i.e. texture, aroma and flavour). The crispy outer crust with moist inner part enhances palatability of the food. Besides domestic cooking, deep frying method is being used commercially in restaurants (including fast food restaurants), mass catering and

Malaysian Palm Oil Board,

6 Persiaran Institusi, Bandar Baru Bangi,

43000 Kajang, Selangor, Malaysia.

E-mail: nurhaqim.ismail@mpob.gov.my various food industries (including snack industry). Fast food restaurants have been experiencing exponential growth worldwide, especially in big cities due to changes in lifestyles when people have limited time to prepare daily meals (Shaharudin et al., 2011). The popularity of fast food restaurants among the younger generation is undeniable as they offer menus with affordable prices, easy to access and convenient (Habib et al., 2011), complemented with good marketing and advertising strategies.

Numerous types of lipids, in the form of liquid, solid and semi-solid at room temperature are available in the market for deep frying. These lipids act as a medium for heat transfer to the food. Despite being simple, fast and convenient, deep frying is a complex process and may result in physical and chemical changes when the lipids are being used repeatedly at a high temperature of between $150^{\circ} \mathrm{C}-200^{\circ} \mathrm{C}$ (thermal degradation) (Ahmad Tarmizi 
et al., 2016). This degradation depends on the type of lipids, products, temperature, time as well as frying process (batch or continuous). Thermal degradation may include oxidative, hydrolytic and polymerisation reactions as listed in Table 1, that produce displeasing breakdown products which may affect organoleptic properties and nutritive value of the food (Andrikopoulos et al., 2003; Gertz, 2000). Toxic compounds which are being produced during frying at prolonged time and repeated use of oils are likely to increase at high concentrations (Ghobadi et al., 2018). About 4\%-14\% of frying oils and fats are absorbed into the food structure during frying (Andrikopoulos et al., 2002; 2003; Goburdhum and Jhuree, 1995). Thus, the quality of fried food products is largely affected by the quality of lipids used in the frying. The undesirable breakdown products from thermal degradation may affect human health (Innawong et al., 2004).

TABLE 1. PHYSICAL AND CHEMICAL PROPERTIES CHANGES OF FRYING OILS AND FATS DURING FRYING

\begin{tabular}{lll}
\hline Category & \multicolumn{1}{c}{ Reaction } & \multicolumn{1}{c}{ Changes } \\
\hline Physical & $\begin{array}{l}\text { Aeration, vapourisation, } \\
\text { foaming, smoke, } \\
\text { solubilisation, } \\
\text { colouration }\end{array}$ & $\begin{array}{l}\text { Viscosity, density, } \\
\text { tension, dielectric } \\
\text { constant and } \\
\text { conductivity }\end{array}$ \\
Chemical & $\begin{array}{l}\text { Hydrolysis, auto- } \\
\text { oxidation, dehydration, } \\
\text { polymerisation, } \\
\text { cyclisation and Maillard } \\
\text { reactions }\end{array}$ & $\begin{array}{l}\text { Polar compound, } \\
\text { polymer compound, } \\
\text { free fatty acid, fatty } \\
\text { acid composition, } \\
\text { rancidity and peroxides }\end{array}$ \\
\hline
\end{tabular}

Source: Ahmad Tarmizi et al. (2016).

Various methods are used to evaluate the quality of the frying oils used in the fast food restaurants. A simple and easy method is visual inspection of oil for physical changes in the colour and odour and check for excessive smoking and foaming. However, colour changes in the oil is not an accurate method and specification of the exact time for oil replacement based on colour change is difficult as it depends on human judgement (Ghobadi et al., 2018; Ibrahim et al., 2019). Moreover, the changes are only visible when the oils are already unsafe to be consumed. Chemical parameters include the total polar compounds, polymers, free fatty acids or acid value and viscosity are more reliable as the extent of the oils degradation are evaluated (Ibrahim et al., 2019).

To date, there is no reference on the quality of the frying oils used in fast food restaurants in Malaysia. The objective of this survey was to study the quality of oils used for frying in four selected fast food restaurants in east coast of Malaysia. Fresh, in-use and discarded frying oils from the fast food restaurants were analysed for their oxidative stability index (OSI), smoke point, colour (redness), free fatty acid (FFA), polar compound, peroxide value $(P V), \rho$-anisidine value $(\rho-A V)$ and total oxidation (TOTOX) value.

\section{MATERIALS AND METHODS}

\section{On-site Sampling}

Fresh, in-use and discarded oils were collected from four fast food restaurants. Table 2 describes the type of oils, usage of the fats and oils and days of frying. Frying procedures at all restaurants were different from each other in terms of the type of oil, food, fryers and frying conditions. Restaurants $\mathrm{A}$ and $\mathrm{D}$ used refined, bleached and deodourised (RBD) palm olein, and Restaurant C used RBD palm oil for frying of all products in their outlets. Restaurant B used palm olein to fry fries, whereas palm oil was used for frying other products. Fresh oil was taken directly from the storage container. The in-use oil was taken straight from the fryers, regardless the type of food being fried and the days of frying. Discarded oil was taken from the designated discard oil drums (oils from all fryers). One $\mathrm{kg}$ of each type of cooking oils (samples) was filled into Amber glass bottles. The samples were filled about $2 \mathrm{~cm}$ from the opening of the bottles as this method could avoid the photo-oxidation and headspace oxidation during transportation and storage of the oils before the analysis.

\section{Samples Preparation}

All oil samples were melted in an oven at $60^{\circ} \mathrm{C}$ and filtered using filter cloth to remove sediments. The oil was transferred to a clean Amber bottle, sparged with nitrogen and stored at $-18^{\circ} \mathrm{C}$ for further analyses.

\section{FFA}

FFA was analysed according to the Association of Official Analytical Chemists' Official Method Ca 5a-40 (AOCS, 2009). The $20 \mathrm{~g}$ of oil samples were dissolved in $50 \mathrm{ml}$ isopropanol and $2 \mathrm{ml}$ phenolphthalein was added as the indicator solution. The mixture was titrated with $0.1 \mathrm{M}$ sodium hydroxide until the first permanent pink colour appeared and remained for at least $30 \mathrm{~s}$. The FFA was expressed as the percentage of palmitic acid.

\section{Smoke Point}

The smoke point of oils was analysed according to AOCS Official Method CC 9a-48 (2012). The oil 
TABLE 2. TYPES, USAGE AND DAYS OF FRYING OF FATS AND OILS FROM FOUR FAST FOOD RESTAURANTS IN EAST COAST OF MALAYSIA

\begin{tabular}{|c|c|c|c|}
\hline Restaurant & $\begin{array}{l}\text { Types of } \\
\text { oils/fats }\end{array}$ & Usage & $\begin{array}{c}\text { Days of } \\
\text { frying }\end{array}$ \\
\hline \multirow[t]{8}{*}{ A } & Palm olein & Fresh & - \\
\hline & & Fries & 6 \\
\hline & & Fries & 6 \\
\hline & & Chicken (original) & 6 \\
\hline & & Chicken (spicy) & 6 \\
\hline & & Chicken (spicy) & 6 \\
\hline & & Chicken (spicy) & 6 \\
\hline & Discarded & & - \\
\hline \multirow[t]{5}{*}{ B } & Palm oil & Fresh & - \\
\hline & & Fries & 2 \\
\hline & & Chicken & 3 \\
\hline & & $\begin{array}{l}\text { Chicken mixed } \\
\text { (patty/fillet/nugget/ } \\
\text { bites) }\end{array}$ & 3 \\
\hline & Discarded & & - \\
\hline \multirow[t]{11}{*}{$\mathrm{C}$} & Palm olein & Fresh & - \\
\hline & & Fries & 6 \\
\hline & Palm oil & Fresh & - \\
\hline & & Sweet dessert & 6 \\
\hline & & Chicken nugget & 6 \\
\hline & & Chicken patty & 6 \\
\hline & & Chicken patty & 6 \\
\hline & & Chicken patty & 6 \\
\hline & & Chicken (spicy) & 6 \\
\hline & & Chicken (original) & 6 \\
\hline & Discarded & & - \\
\hline \multirow[t]{6}{*}{$\mathrm{D}$} & Palm olein & Fresh & - \\
\hline & & Chicken (original) & 3 \\
\hline & & Chicken (spicy) & 3 \\
\hline & & $\begin{array}{l}\text { Chicken mixed } \\
\text { (patty/fillet/nugget) }\end{array}$ & 3 \\
\hline & & Fries & 3 \\
\hline & Discarded & & - \\
\hline
\end{tabular}

was heated rapidly to within $42^{\circ} \mathrm{C}$ of the smoke point followed by regulated heating $5^{\circ} \mathrm{C}-6^{\circ} \mathrm{C}$ per minute until the presence of a thin and continuous bluish smoke.

\section{OSI}

OSI was evaluated according to the Association of Official Analytical Chemists' Official Method Cd 12b-92 (AOCS, 2009) using Rancimat 743 (Metrohm, Switzerland). The oil samples were melted at $60^{\circ} \mathrm{C}$ in an oven before being weighed directly in the reaction tubes. The reaction tubes were placed in the heating block and the analysis started immediately. The evaluation parameters were: sample weight, $3.0 \pm 0.1 \mathrm{~g}$; heating temperature, $110^{\circ} \mathrm{C}$; gas flow, 20 litre $\mathrm{hr}^{-1}$; and absorption solution, $60 \mathrm{ml}$. OSI result was translated as induction time.

\section{Colour}

Colour was determined according to ISO 15305 (1998) using a Tintometer Model E (Lovibond, Amesbury, England). The oil samples were heated to $60^{\circ} \mathrm{C}$ in an oven and placed in glass cells, 5.25 inches and 1 inch $(13.3$ and $2.5 \mathrm{~cm})$ path lengths. The cell containing the oil sample was placed within the lighting cabinet. The lid of the lighting cabinet was closed and colour of the cooking oil sample was determined immediately using colour racks.

\section{Polar Compound}

Polar compound was analysed gravimetrically according to IUPAC 2.507 (IUPAC, 1992). One gram of oil sample was dissolved in $8 \mathrm{ml}$ of $90 \%$ petroleum ether (PE) and 10\% diethyl ether (DE) mixture. The mixture was then transmitted to a glass chromatography column, which was packed with 7 $\mathrm{g}$ of Silica Gel 60 suspended in the PE-DE mixture, and covered with a layer of sea sand $(1 \mathrm{~g})$. The column was rinsed with $100 \mathrm{ml}$ of PE-DE mixture for 60-70 $\mathrm{min}$ to separate the non-polar fraction. The polar fraction was eluted using approximately $100 \mathrm{ml}$ of DE within 60-70 min. Both polar and nonpolar fractions were collected in separate flasks. Solvent was evaporated from the polar fraction using a rotary evaporator (Büchi Labortechnik AG, Flawil, Switzerland). Nitrogen was purged into the system from a rubber bulb before the termination of distillation. The residues were dried to constant weight at $105^{\circ} \mathrm{C}$ using an oven. The mass of polar compounds was determined from the residue obtained from the polar fraction.

\section{PV}

The PV was measured according to procedures described in ISO 3960 (2001). The oil samples were dissolved in the mixture of isooctane and glacial acetic acid (40:60) and allowed to react with freshly prepared saturated solution of potassium iodide $(\mathrm{KI})$ for $60 \mathrm{~s}$. Free iodine $\left(\mathrm{I}_{2}\right)$ was specified by titration of the desired mixture with standard sodium thiosulfate $\left(\mathrm{Na}_{2} \mathrm{~S}_{2} \mathrm{O}_{3} ; 0.01 \mathrm{M}\right)$ in presence of starch solution $(1 \mathrm{~g} / 100 \mathrm{ml})$ as the indicator.

$\rho-A V$

The $\rho$-AV was measured according to the procedures described in AOCS Official Method Cd 18-90 (AOCS, 2011). About $0.5 \mathrm{~g}$ oil sample was dissolved in iso-octane until a total volume of $25 \mathrm{ml}$ was obtained. Five $\mathrm{ml}$ of the solution was drawn out and further reacted with $1 \mathrm{ml}$ of $\rho$-anisidine solution containing $\rho$-anisidine and glacial acetic acid. The $\rho-\mathrm{AV}$ was analysed based on colour intensity using a CECIL Spectrophotometer 1000 Series (CECIL Instruments Ltd, Cambridge, United Kingdom) at a 
wavelength of $350 \mathrm{~nm}$. Colour intensity is reflected as yellowish colour formed from the reaction solution which correlates with the presence of aldehydic components in the sample.

\section{TOTOX}

TOTOX was calculated as TOTOX $=2 \mathrm{PV}+\rho-\mathrm{AV}$, where PV and $\rho$-AV represent peroxide value and $\rho$-anisidine value, respectively (Sebastian et al., 2014).

\section{Data Analysis}

Results were tabulated as mean values \pm standard deviation of three replicates.

\section{RESULTS AND DISCUSSION}

\section{FFA}

FFA is one of the most broadly used parameter to determine the quality of the frying oil (Chen et al., 2013). It is measured based on the amount of potassium hydroxide required to compensate the FFA present in $1 \mathrm{~g}$ of oil. FFA is formed from the decomposition of hydroperoxides due to the presence of moisture and air at high temperature during frying process (Nayak et al., 2016). Malaysia has set the maximum limit of FFA at $0.1 \%$ for both RBD palm oil and palm olein (Malaysian Standard, 2007). Ismail (2005) reported that the maximum threshold allowed for the FFA is differed by the type of fried food. For example, the FFA threshold of oil for potato chips frying on the industrial production scale is $0.5 \%$, whereas the threshold of $1 \%$ of FFA was set for the processors of pre-fried French fries. However, a higher threshold (2.0\%-2.5\%) is tolerated for the oils used to fry battered and breaded products (Ahmad Tarmizi et al., 2013). Some countries have set the regulation on the maximum limit of FFA threshold before discarding the frying oil. These include Germany (1\%), Austria (1.25\%), Japan (1.25\%), Netherlands (2.25\%) (Rossell, 1997) and United States (2\%) (Sebastian et al., 2014).

The FFA of fresh oils from all restaurants was in the range of $0.03 \%-0.1 \%$, which complies with the maximum FFA limit set by the Malaysian Standard (Table 3). The FFA of the in-use oils was higher than those of fresh oil, varied between $0.41 \%-8.41 \%$ (Table 4). The FFA values increased as the time of frying increased, suggested that the triacylglycerol molecules in the frying oil have undergone hydrolytic deterioration. A similar result was reported by Ibrahim et al. (2019). They expected that the difference in the FFA value was due to the polymerisation and hydrolysis reaction in the oil that take place during frying. The in-use oils to fry fries in Restaurants A, B and D, and to fry breaded products by Restaurants $\mathrm{C}$ and $\mathrm{B}$ were beyond the maximum threshold of $0.5 \%$ and $2.5 \%$, respectively. The highest FFA was noted in the in-use oil from Restaurant C which was used to fry chicken. Ali et al. (2014) and Enríquez-Fernández et al. (2011) reported that the FFA of oil used to fry chicken nuggets was higher compared to the oil used to fry french fries. However, a contrary observation was detected in the in-use oils used to fry fries in Restaurants A, $\mathrm{C}$ and $\mathrm{D}$ where the FFA was higher compared to the in-use oils used to fry chicken products. The finding was similar with Pokorny (1998) where the frying oil used to fry starch oxidised faster than the frying oil used to fry protein substrates. This was due to the reaction of the lipid peroxides with the remainder of the amino acid in the protein. The FFA of the discarded oil was in the range of $1.47 \%-7.72 \%$ (Table 5). The highest FFA level in the in-use oil and discarded oil was 8.41 and 7.72, respectively, which have exceeded the regulatory guidelines from any countries mentioned above. Ahmad Tarmizi and Siew (2008) reported that the development of FFA is highly correlated with the smoke point in which higher FFA content lowers the smoke point. A similar pattern of results was observed in the present studies (Tables 4 and 5). The smoke point of the in-use and discarded oils was decreased along with the increase of FFA.

\section{Smoke Point}

Smoking is the signal that fat has broken down chemically to produce glycerol and fatty acids. The glycerol is then further broken down to acrolein, a main component of the smoke (McGill, 1980). A survey on the worldwide regulation of frying fat and oil revealed that some countries had set their legal minimum limit for the smoke point of frying oil (Firestone, 1993). Austria, Belgium, Finland, Germany, Japan and Switzerland had set a limit of $170^{\circ} \mathrm{C}$, whilst Hungary had set a limit of $180^{\circ} \mathrm{C}$. Frying fats and oils with smoke point of more than $200^{\circ} \mathrm{C}$ are recommended for frying as the fats and oils will not produce smoke albeit first used (Mba et al., 2015). Eyres (2015) stated that a higher smoke point is a beneficial property of cooking oil. Smaller, more volatile components, especially fatty acids reduce the smoke point and the reduction is maintained during the time of frying until the oil is no longer usable. At this point, the smoke point is less than $170^{\circ} \mathrm{C}$. Typically, the smoke point of fresh palm oil is $230^{\circ} \mathrm{C}$ (Mba et al., 2015) and palm olein is $220^{\circ} \mathrm{C}$ (Fan et al., 2013). In the present study, the temperature of $170^{\circ} \mathrm{C}$ was used as the minimum limit of smoke point of the oils. The smoke point of fresh oils used in all restaurants was in the range of $214.7^{\circ} \mathrm{C}-237.3^{\circ} \mathrm{C}$ (Table 3) which indicates that the fresh palm oil and palm olein have excellent smoke 
point. The in-use oils was noticed to have lower range of smoke point between $135.6^{\circ} \mathrm{C}-205^{\circ} \mathrm{C}$ (Table $4)$. The results describe that 12 samples $(57.1 \%)$ of the in-use oils have smoke point below of $170^{\circ} \mathrm{C}$. The results indicate that the frying operation lowers the smoke point of the frying oils. During frying, FFA forms from the hydrolysis of triglycerides and breakdown of hydroperoxide occurs at high temperature in the presence of moisture and air (Nayak et al., 2016). The formation of aldehydes, which is the major products of FFA, induces the formation of acrolein (Katragadda et al., 2010), which is the major component of the smoke. The smoke point of the discarded oils from all restaurants was in the range of $140.3^{\circ} \mathrm{C}-161.3^{\circ} \mathrm{C}$, below the minimum limit of $170^{\circ} \mathrm{C}$ (Table 5).

\section{Oxidative Stability}

Rancimat is the most common accelerated method used to determine the oxidative stability of fats and oils and fat-containing food (Hadorn and Zurcher, 1974). Rancimat method evaluates the stability of the oil towards oxidation based on the induction time. The longer the induction time relates to the higher stability of the oil (Kowalski et al., 2004; Farhoosh et al., 2008). OSI of fresh oils in terms of induction time is tabulated in Table 3. The OSI of the fresh oils used by the fast food restaurants ranged from 20.8-54.8 hr. Fresh oils from Restaurants A and $\mathrm{B}$ had the highest OSI which was 54.4 and $54.8 \mathrm{hr}$, respectively. Fresh oils from Restaurants C and D had OSI that resembled the OSI of RBD palm oil and/or palm olein, which was 20.6-33.9 hr. High OSI of the fresh oils from Restaurants A and B was most probably due to the addition of permitted synthetic antioxidants such as tert-butylhydroquinone (TBHQ), butylated hydroxyanisole (BHA) and butylated hydroxytoluene (BHT). These synthetic antioxidants are commonly being used in the edible oil by the industries such as Malaysia, China, Peru, Australia and America, due to being widely available, cost effective and able to delay the oxidative rancidity in the oil (Liu et al., 2016). The OSI of the in-use oils was in the range of 5.0$36.8 \mathrm{hr}$ (Table 4). The stability of the oils collected from the fast food restaurants towards oxidation decreased gradually as the frying commenced, parallel with the findings reported by Ahmad Tarmizi et al. (2016). According to Ahmad Tarmizi et al. (2016), the induction time of palm olein and blended oils was decreasing for the first five days of frying due to the deterioration of vitamin $\mathrm{E}$ in the oil. From these results it is clear that higher induction hour in frying breaded products which contained chicken might be due to the saturated fatty acids content in the chickens leaching into the frying oil compared to fries which was mainly the carbohydrate.

\section{Colour}

Colour is a common parameter to determine oil quality. According to Maskan (2003), changes in oil colour during frying is the result of oxidation, polymerisation and other chemical changes. The rapid changes of oil colour from a light yellow to a dark orange-brown indicates that the oil has undergone deterioration. The oil colour darkening can also be affected by the foods being fried as the colour of the frying food tends to diffuse in the oil (Melton et al., 1994). The maximum colour of RBD palm oil (MS 814:2007) and palm olein (MS $816: 2007)$ set by the Malaysian Standard (2007) is 3.0R based on the 5.25" Lovibond cell. The colour of fresh oils from all restaurants was in the range of 1.7 to $2.1 \mathrm{R}$, showing that the fresh oils complied with the standard (Table 3). Drastic increase in the redness and yellowness values (darkening) was observed in oils used for frying food in all restaurants (Table 4 ). The colour of the in-use oils from all restaurants was in the range of 7.4 to $29.9 \mathrm{R}$. The colour of the discarded oils was in the range of 14.3 to $28.8 \mathrm{R}$ (Table 5).

The changes in colour may be associated with the thermal and auto-oxidation by the existence of phospholipids which darkens upon heating (Latha and Nasirullah, 2014). The darkening of the oil might be due to the presence of pieces of food which accelerate the oil darkening (Lin et al., 2001) and are affected by the type of food being fried and the time of frying (Ahmad Tarmizi et al., 2013; EnríquezFernández et al., 2011) and products of Maillard reaction which took place in the presence of sugar and amino acids also lead to the darkening of oil (Nayak et al., 2016). Enríquez-Fernández et al. (2011) observed that the darkening of oil was higher in the oil used for frying chicken nuggets compared to the fries, due to the fat leaching out from the nugget into the oil. Ahmad Tarmizi et al. (2013) reported that the darkening (more reddish and yellowish) of oil was increased as the frying progressed. The darkening of the colour of frying oil is also highly affected by the type of oil used for frying. A study by Abdulkarim et al. (2007) on colour changes in different oils during frying affirmed that the colour of palm olein was the highest on Day 1 of the frying but the rate of the darkening slowed down and became constant throughout the frying study. After five days of frying, the colour of palm olein was lighter than the colour of canola and soyabean oils. A comparative study by Razali et al. (1999) found that the darkening of palm olein was faster than the high oleic sunflower oil. However, the colour of the fried products was not affected by the darker colour of palm olein. Irwandi et al. (2000) suggested that the increase in the darkness of oils was contributed by the oxidation and polymerisation of unsaturated fatty acids in the frying oil. The darkening of the 
oil after frying was also influenced by the buildup of non-volatile decomposition products such as free fatty acids and oxidised triacylglycerols (Abdulkarim et al., 2007). Nayak et al. (2016) suggested that the oil colour darkening can be a beneficial indicator to prevent further frying activities of the oil which has endured extreme deterioration. However, it must not be the main parameter of the exact time to change the oil as this is not an accurate method (Ghobadi et al., 2018).

\section{Polar Compound}

A study by Bansal (2010) suggested that polar compound can be considered as the primary parameter that indicates the quality of the frying oils. The development of polar compounds indicates the deterioration of the oil which is strongly associated with both primary and secondary oxidation during frying activity (Karakaya and Simsek, 2011). The non-volatility of polar compound reflects major reactions from the degraded oils and fats (Warner and Gupta, 2003). Many countries have set the maximum level of polar compound obliged in the frying oil. For example, France, Italy, Belgium, Chile, Spain and South Africa have set the maximum level of $25 \%$ for the polar compound while Austria and Germany have set a maximum limit to 27\% (Berger, 2005). In the present study, the maximum limit of $27 \%$ was used as the limit of polar compound.

The polar compound of fresh oils collected from the fast food restaurants ranged from $4.44 \%$ $7.76 \%$ (Table 3). These values indicate that the oils used are fresh. The polar compound of the in-use frying oils ranged from $6.57 \%-47.77 \%$ (Table 4). It is alarming when polar compound in most of the in-use oils from Restaurants C and D had exceeded the recommended maximum limit of $27 \%$. Surprisingly, the polar compound of the in-use oils from Restaurant D (Table 4) had exceeded the maximum level at Day 3 of frying. This restaurant discards the oils use for frying every six days. Low polar compound in the in-use oils from Restaurants $A$ and $B$ can be associated with the addition of synthetic antioxidants in the fresh oil. In recent study, Díaz-Sánchez et al. (2019) reported that the palm olein with the addition of antioxidants had lower polar compound than palm olein without the addition of antioxidants in industrial continuous frying. Banu et al. (2016) also claimed that the polar compound was lower in the frying oils with the addition of 200 ppm of TBHQ compared to those without TBHQ. Polar compound of the discarded oils from these fast food restaurants ranged from $17.32 \%-40.01 \%$ (Table 5). Polar compound of the discarded oils from Restaurants C and D exceeded the maximum allowance of $27 \%$. However, polar compound analysis does not provide an accurate estimation of the oils' degradation; therefore, other decisive factors such as $\rho-\mathrm{AV}$ should be considered too (Esfarjani et al., 2019).

\section{PV}

The PV is an indicator of the primary oxidative state of oils. PV indicates products from the initial reaction of lipid oxidation such as alkanes, alkenes, hydroperoxides, ketones, epoxides, aldehydes and carboxylic acids (Qin, 2011; Tian, 2013). The hydroperoxides are further broken down at high temperature to form secondary oxidation products. Generally, freshly refined oils have PV of less than $1 \mathrm{meq} \mathrm{kg}^{-1}$ oil. The oil is regarded as rancid at PV of more than $10 \mathrm{meq} \mathrm{kg}^{-1}$ oil (Gunstone, 2008). It is clear that there were variation in the PV of fresh oil, from 0.34 to $1.28 \mathrm{meq} \mathrm{kg}^{-1}$, with the PV of fresh oils from Restaurants B and D above the limit of 1 meq $\mathrm{kg}^{-1}$ (Table 3). The PV of the in-use oils ranged from 0.54-7.27 (Table 4). These results clearly indicated that none of the samples had PV above the limit of $10 \mathrm{meq} \mathrm{kg}^{-1}$. A similar study done by Sebastian et al. (2014) on the quality of frying oils used in restaurants in Toronto, Canada, found that the PV of fresh frying oils from all restaurants in their study was above the limit of $1 \mathrm{meq} \mathrm{kg}^{-1}$ and $35 \%$ of the in-use oils have PV above the limit of 10 meq $\mathrm{kg}^{-1}$. Ghobadi et al. (2018) reported that high PV was detected in the frying oils collected from the fast food restaurants in Shiraz, Iran. EnríquezFernández et al. (2011) claimed that the final PV of palm olein used to fry carbohydrate-based product was lower than protein-based product. The finding was in contrast with the PV in this study. We encountered that the PV of oils used to fry fries was higher than chicken products. The PV of the discarded oils ranged from 0.47-4.79 (Table 5) meq $\mathrm{kg}^{-1}$, which is within the maximum limit of 10 meq $\mathrm{kg}^{-1}$. Similar research by Esfarjani et al. (2019) reported that the mean of PV of the discarded oils collected from the fast food restaurants in Tehran, Iran, was 3.06 meq $\mathrm{kg}^{-1}$. Nonetheless, PV can only detects the primary oxidation. PV may surge even after the oil is taken from the fryer. Thus, it is not a decisive method to conclude the oxidation state occurred inside the oil (Man and Hussain, 1998). For this rationale, the $\rho-\mathrm{AV}$ was determined to measure the secondary oxidation products as to access the quality of these oils.

\section{$\rho-\mathrm{AV}$}

The $\rho$-AV measures the amount of aldehyde in oil, particularly 2,4-dienals and 2-alkenals. These products are produced during the secondary oxidation of lipids (Tompkins and Perkins, 1999). The products produced during the secondary oxidation are more stable compared to the peroxide 


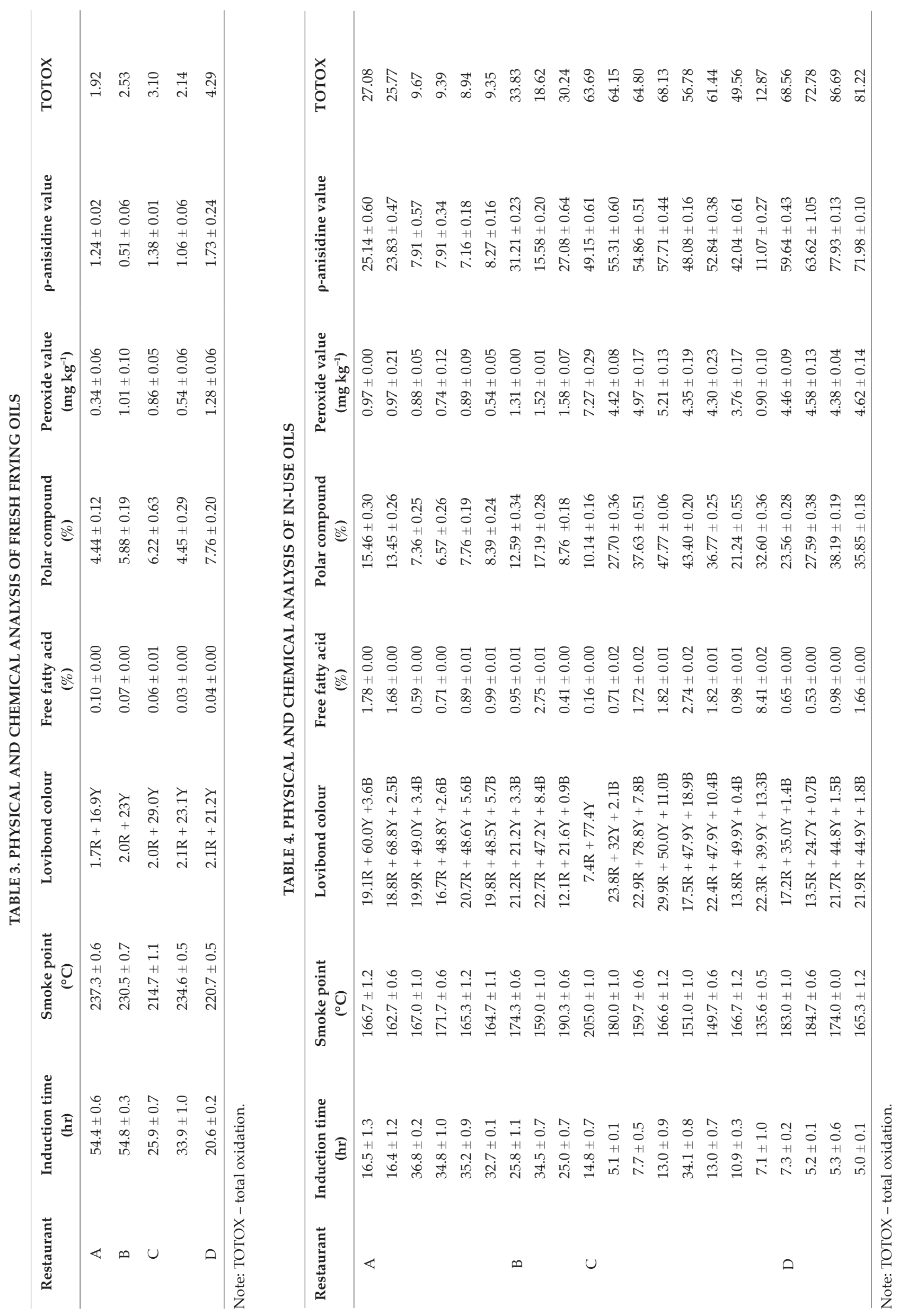


TABLE 5. PHYSICAL AND CHEMICAL ANALYSIS OF DISCARDED OILS

\begin{tabular}{|c|c|c|c|c|c|c|c|c|}
\hline Restaurant & $\begin{array}{l}\text { Induction } \\
\text { time } \\
\text { (hr) }\end{array}$ & $\begin{array}{c}\text { Smoke } \\
\text { point } \\
\left({ }^{\circ} \mathrm{C}\right)\end{array}$ & $\begin{array}{l}\text { Lovibond } \\
\text { colour }\end{array}$ & $\begin{array}{c}\text { Free fatty } \\
\text { acid } \\
(\%)\end{array}$ & $\begin{array}{c}\text { Polar } \\
\text { compound } \\
(\%)\end{array}$ & $\begin{array}{l}\text { Peroxide } \\
\text { value } \\
\left(\mathrm{mg} \mathrm{kg}^{-1}\right)\end{array}$ & $\begin{array}{l}\rho \text {-anisidine } \\
\text { value }\end{array}$ & TOTOX \\
\hline A & $31.3 \pm 0.8$ & $140.3 \pm 2.1$ & $19.9 \mathrm{R}+31.8 \mathrm{Y}+14.7 \mathrm{~B}$ & $4.02 \pm 0.03$ & $17.32 \pm 0.28$ & $0.47 \pm 0.06$ & $5.99 \pm 0.34$ & 6.93 \\
\hline B & $8.1 \pm 1.1$ & $161.3 \pm 1.2$ & $28.8 \mathrm{R}+26.9 \mathrm{Y}+2.5 \mathrm{~B}$ & $1.47 \pm 0.01$ & $22.60 \pm 0.36$ & $4.79 \pm 0.11$ & $59.92 \pm 0.30$ & 69.50 \\
\hline $\mathrm{C}$ & $14.9 \pm 0.8$ & $145.7 \pm 0.6$ & $14.3 R+23.9 Y+25.3 B$ & $7.72 \pm 0.07$ & $33.94 \pm 0.41$ & $1.81 \pm 0.09$ & $27.34 \pm 0.44$ & 30.96 \\
\hline $\mathrm{D}$ & $31.9 \pm 2.4$ & $147.3 \pm 1.2$ & $22.4 \mathrm{R}+40.4 \mathrm{Y}+15.5 \mathrm{~B}$ & $3.98 \pm 0.05$ & $48.01 \pm 0.22$ & $3.88 \pm 0.14$ & $61.64 \pm 0.49$ & 69.40 \\
\hline
\end{tabular}

Note: TOTOX - total oxidation.

compounds produced in the primary oxidation of lipids (Sebastian et al., 2014). Gupta (2005) described that the $\rho-\mathrm{AV}$ of a good quality fresh oil should be less than 4.0 with not more than 6.0. Oils with $\rho-\mathrm{AV}$ of more than 6.0 is classified as extremely oxidised. However, Rossell (1989) suggested that the $\rho-\mathrm{AV}$ should be less than 10 for good quality oil. The $\rho$-AV of the fresh oils from the fast food restaurants participated in this study was in the range of 0.511.73. Based on the results obtained, none of the fresh oil had $\rho-\mathrm{AV}$ of more than 6 , although the PV of the fresh oil from Restaurants B and D was more than 1 meq $\mathrm{kg}^{-1}$ (Table 3) indicating that the fresh oils used in all restaurants were good quality oil. There was a tremendous increase in $\rho-\mathrm{AV}$ in the inuse oils compared to the fresh oils. As high as $81 \%$ of the collected in-use oils having $\rho$-AV of more than 10 (Table 4). The lowest $\rho$-AV was noted from Restaurant A with $\rho$-AV of 7.16 while the highest was from Restaurant D with $\rho-\mathrm{AV}$ of 77.93. Karimi et al. (2017) reported that $\rho-\mathrm{AV}$ of the inuse oils collected from 11 commercial vendors around Nairobi city, Kenya, ranged from 7.7-42.1. Aladedunye and Przybylski (2009) explained that the $\rho-A V$ increases along with the frying time. A similar finding was reached by Ahmad Tarmizi et al. (2013). They found that the $\rho-\mathrm{AV}$ increased gradually after five days of frying fries. Mahboubifar et al. (2016) also reported that the $\rho$-AV of the studied vegetable oils was increased moderately within $24 \mathrm{hr}$ of frying and after that, the $\rho-A V$ increased significantly. As mentioned earlier, the PV of oils used to fry fries was higher than the chicken products, and we encountered the same trend in $\rho-\mathrm{AV}$. The $\rho-\mathrm{AV}$ of the chicken products in Restaurant A was the lowest compared to the other restaurants. It may be suggested that Restaurant A might practice a good oil management system in their frying procedures. It is very important to maintain a good oil management in the restaurant such as to have a schedule in the replenishment of the frying oil with the fresh oil. Aladedunye and Przybylski (2014) observed an elevated $\rho$-AV of the frying oils for the first two days of frying. However, the $\rho-\mathrm{AV}$ of the oils reached a plateau after that point. They suggested that the replenishment of frying oil with the fresh oil every day of frying contributed to the leveling of the $\rho-\mathrm{AV}$. The $\rho-\mathrm{AV}$ of the discarded oils was in the range of 5.99-61.64 (Table 5). Similar research by Esfarjani et al.(2019) stated that the $\rho-\mathrm{AV}$ of the discarded samples collected in Tehran was 58.

\section{TOTOX}

TOTOX is typically used to explicit the overall oxidation state of the frying oils which combines the PV and $\rho-\mathrm{AV}$. Generally, the recommended level of TOTOX value is less than or equal to 19.5 meq $\mathrm{kg}^{-1}$, which increases linearly with both PV and $\rho-\mathrm{AV}$ (De Abreu et al., 2010). Wai et al. (2009) noted that the lower the TOTOX value, the better quality of the oil as it is less susceptible to oxidative deterioration. TOTOX value of fresh oils from all restaurants was in the range of 1.92-4.29 (Table 3). It was observed that the values increased in the in-use oils. The TOTOX value of the in-use oils was in the range of 8.94-86.69 (Table 4). The highest TOTOX value was noted in the in-use oil from Restaurant D which was used to fry mixed products only after three days of frying. The lowest TOTOX value was observed in the in-use oil from Restaurant A which was used to fry original fried chicken indicating that the oil used in the restaurant was stable towards oxidative rancidity. The TOTOX value of the discarded oil was in the range of 6.93-69.50 with the highest from Restaurant B while the lowest from Restaurant A (Table 5).

\section{CONCLUSION}

The fast food restaurants in this study used RBD palm olein and/or palm oil as the frying medium for their food products. The fresh oils from all restaurants were of good quality for frying which were all below the maximum limit of smoke point, colour, FFA, polar compound, $\rho-\mathrm{AV}$ and have high oxidative stability index, making these oils good choice as the frying oils. Undoubtedly, frying activities deteriorated the quality of these oils by decreasing the smoke point and OSI, darkened 
the colour and increased the levels of FFA, polar compound, PV and $\rho-\mathrm{AV}$. The fast food restaurants in this study continued with their frying activities regardless of the state of the oils. Regardless the addition of synthetic antioxidants in the fresh oil, the oxidation state of the oils were alarming especially in Restaurant D where the oxidation state was the highest although the oils were used on Day 3. To ensure the safety of the consumption of these frying products from the fast food restaurants, it is suggested that inspection of the quality of the oils used in the fast food industry be implemented regularly as to maintain the quality of the products as well as the health of the consumers. On top of that, adequate training on the proper oil management can be given to the operators who are involved directly and indirectly with the frying activities in the premises to ensure that the fast food operators do not abuse the frying oils for their commercial frying activities. Based on the results of this study, it is crucial for an extensive study to be done to investigate the quality and the safety of the oils used for frying from various premises which operate the frying activities as this kind of studies could give a broad perspective of the oxidation process in frying oil related to the frying conditions.

\section{ACKNOWLEDGEMENT}

The authors would like to acknowledge the management of MPOB for funding this research work.

\section{REFERENCES}

Abdulkarim, S M; Long, K; Lai, O M; Muhammad, S K S and Ghazali, H M (2007). Frying quality and stability of high-oleic Moringa oleifera seed oil in comparison with other vegetable oils. Food Chem., 105: 1382-1389.

Ahmad Tarmizi, A H and Siew, W L (2008). Quality assessment of palm products upon prolonged heat treatment. J. Oleo Sci., 57(12): 639-648.

Ahmad Tarmizi, A H; Niranjan, K and Gordon, M (2013). Physicochemical changes occurring in oil when atmospheric frying is combined with postfrying vacuum application. Food Chem., 136: 902908.

Ahmad Tarmizi, A H; Karimah, A; Miskandar, M S and Choo, Y M (2016). Rancimat test for measuring oxidative stability of cooking oils upon prolonged frying: Short communication. J. Oil Palm Res. Vol. 28(4): 531-535.
Aladedunye, F and Przybylski, R (2009). Degradation and nutritional quality changes of oil during frying. J. Amer. Oil Chem. Soc., 86: 149-156.

Aladedunye, F and Przybylski, R (2014). Performance of palm olein and modified rapeseed, sunflower, and soybean oils in intermittent deep-frying. Euro J. Lipid Sci. Tech., 116: 144-152.

Ali, M A; Daud, A S M; Latip, R A; Othman, N H and Islam, M A (2014). Impact of chicken nugget presence on the degradation of canola oil during frying. Intl. Food Res. J., 21(2): 1119-1124.

Andrikopoulos, N K; Dedoussis, G V Z; Falirea, A; Kalogeropoulos, N and Hatzinikola, H S (2002). Deterioration of natural antioxidant species of vegetable oils during the domestic deep-frying and pan-frying of potatoes. Intl. J. Food Sci. Nutr., 53: 351363.

Andrikopoulos, N K; Boskou, G; Dedoussis, G V Z; Chiou, A; Tzamtzis, V A and Papathanasiou, A (2003). Quality assessment of frying oils and fats from 63 restaurants in Athens, Greece. Food Service Technology, 3: 49-59.

AOCS (2012). Official Methods and Recommended Practices of the American Oil Chemist Society. AOCS Press, Champaign, IL, USA.

AOCS (2011). Official Methods and Recommended Practices of the American Oil Chemist Society. AOCS Press, Champaign, IL, USA.

AOCS (2009). Official Methods and Recommended Practices of the American Oil Chemists' Society. AOCS Press, Champaign, IL, USA.

AOCS (1992). Official Methods and Recommended Practices of the American Oil Chemists' Society. AOCS Press, Champaign, IL, USA.

Bansal, G; Zhou, W; Barlow, P J; Joshi, P S; Hui, L L and Chung, Y K (2010). Review of rapid tests available for measuring the quality changes in frying oils and comparison with standard methods. Crit. Rev. Food Sci., 50(6): 503-514.

Banu, M; Prasad, N and Siddaramaiah (2016). Effect of antioxidant on thermal stability of vegetable oils by using ultrasonic studies. Intl. Food Res. J., 23(2): 528-536.

Berger, K G (2005). The Use of Palm Oil in Frying. Malaysian Palm Oil Promotion Council. 113 pp.

Chen, W A; Chiu, C; Cheng, W C; Hsu, C K and Kuo, M I (2013). Total polar compounds and acid 
values of repeatedly used frying oils measured by standard and rapid methods. J. Food Drug. Anal., 21(1): 58-65.

Díaz-Sánchez, F; Santos-López, E M; Sosa-Morales, M E; Ramírez-Corona, N; Palou, E and López-Malo, A (2019). Stability of palm olein with or without antioxidants during industrial continuous deep-fat frying of wheat snacks. J. Oil Palm Res. Vol. 31(3): 286-293.

De Abreu, D P; Losada, P P; Maroto, J and Cruz, J (2010). Evaluation of the effectiveness of a new active packaging film containing natural antioxidants (from barley husks) that retard lipid damage in frozen Atlantic salmon (Salmo salar L.). Food Res. Int., 43(5): 1277-1282.

Enríquez-Fernández, B E; Yañez, L Á D L C Y and Sosa-Morales, M E (2011). Comparison of the stability of palm olein and a palm olein/canola oil blend during deep-fat frying of chicken nuggets and French fries. Intl. J. Food Sci. Tech., 46: 12311237.

Esfarjani, F; Khoshtinat, K; Zargaraan, A; Mohammadi-Nasrabadi, F; Salmani, Y; Saghafi, Z; Hosseini, H and Bahmaei, M (2019). Evaluating the rancidity and quality of discarded oils in fast food restaurants. Food Sci. Nutr., 7: 2302-2311.

Eyres, L (2015). Frying oils: Selection, smoke points and potential deleterious effects for health. Food New Zealand, 15(1): 30.

Fan, H Y; Sharifudin, M S; Hasmadi, M and Chew, H M (2013). Frying stability of rice bran oil and palm olein. Intl. Food Res. J., 20(1): 403-407.

Farhoosh, R; Niazmand, R; Rezaei, M and Sarabi, $M$ (2008). Kinetic parameter determination of vegetable oil oxidation under Rancimat test conditions. Euro J. Lipid Sci. Tech., 110: 587-592.

Firestone, D (1993). Worldwide regulation of frying fats and oils. INFORM, 4(12): 1366-1371.

Gertz, C (2000). Chemical and physical parameters as quality indicators of used frying fats. Euro J. Lipid Sci. Tech., 102: 566-572.

Ghobadi, S; Akhlaghi, M; Shams, S and Mazloomi, S M (2018). Acid and peroxide values and total polar compounds of frying oils in fast food restaurants of Shiraz, Southern Iran. Intl. J. Nutr. Sci., 3(1): 25-30.

Goburdhum, D and Jhuree, B (1995). Effect of deep fat fry on fat oxidation in soybean oil. Intl. J. Food Sci. Nutr., 46: 363-371.
Gunstone, F D (2008). Oils and Fats in the Food Industry (First ed.). Wiley-Blackwell. United Kingdom. 160 pp.

Gupta, M K (2005). Frying oils. Bailey's Industrial Oil and Fat Products (Shahidi, F ed.). Volume 4. John Wiley and Sons. New Jersey. p. 1-31.

Habib, F Q; Abu Dardak, R and Zakaria, S (2011). Consumers' preference and consumption towards fast food: Evidence from Malaysia. Business and Management Quaterly Review, 2(1): 14-27.

Hadorn, H and Zurcher, K (1974). Zur Bestimmung der Oxydations- stabilitat von $\mathrm{O}^{*}$ len und Fetten. Deutsche Lebensmittel-Rundschau, 70: 57-65.

Ibrahim, N U A; Abd Aziz, S; Hashim, N; Jamaludin, D and Khaled, A Y (2019). Dielectric spectroscopy of palm olein during batch deep frying and their relation with degradation parameters. J. Food Sci., 84(4): 792-797.

Innawong, B; Mallikarjunan, P and Irudayaraj, J (2004). The determination of frying oil quality using a chemosensory system. J. Food Sci. Technol., 37: 35-41.

Irwandi, J; Cheman, Y B and Kitts, D D (2000). Synergistic effect of rosemary and sage extracts and citric acid on fatty acid retention of RBD palm olein during deep-fat frying. J. Amer. Oil Chem. Soc., 77: 527-533.

Ismail, R (2005). Palm oil and palm olein frying applications. Asia Pac. J. Clin. Nutr., 14(14): 414-419.

ISO 15305 (1998). Animal and Vegetable Fats and Oils - Determination of Lovibond Colour. 7 pp.

ISO 3960:2001 (2001). Animal and Vegetable Fats and Oils - Determination of Peroxide Value. 6 pp.

IUPAC (1992). Standard Methods for the Analysis of Oils, Fats and Derivatives. Oxford: International Union of Pure and Applied Chemistry. 151 pp.

Karakaya, S and Şimşek, S (2011). Changes in total polar compounds, peroxide value, total phenols and antioxidant activity of various oils used in deep fat frying. J. Amer. Oil Chem. Soc., 88: 1361-1366.

Karimi, S; Wawire, M and Mathooko, F M (2017). Impact of frying practices and frying conditions on the quality and safety of frying oils used by street vendors and restaurants in Nairobi, Kenya. J. Food Compos. Anal., 62: 239-244.

Katragadda, H R; Fullana, A; Sidhu, S and Barrachina, A A C (2010). Emissions of volatile 
aldehydes from heated cooking oils. Food Chem., 120: 59-65.

Kowalski, B; Ratusz, K; Kowalska, D and Bekas, W (2004). Determination of the oxidative stability of vegetable oils by differential scanning calorimetry and Rancimat measurements. Euro J. Lipid Sci. Tech., 106: 165-169.

Latha, R B and Nasirullah, D R (2014). Physicochemical changes in rice bran oil during heating at frying temperature. J. Food Sci. Technol., 51(2): 335-340.

Lin, S; Akoh, C C and Reynolds, AE (2001). Recovery of used frying oils with adsorbent combinations: Refrying and frequent oil replenishment. Food Res. Int., 34(2-3): 159-166.

Liu, C; Li, J; Bi, Y; Wang, X; Sun, S and Yang, G (2016). Thermal losses of tertiary butylhydroquinone (TBHQ) and its effects on the qualities of palm oil. J. Oleo Sci., 65(9): 739-748.

Mahboubifar, M; Yousefinejad, S; Alizadeh, M and Hemmateenejad, B (2016). Prediction of the acid value, peroxide value and the percentage of some fatty acids in edible oils during long heating time by chemometrics analysis of FTIR-ATR spectra. J. Iran Chem Soc., 13(12): 2291-2299.

Malaysian Standard (2007). Palm Olein Specification (second revision). Department of Standards Malaysia. Cyberjaya, Selangor. 13 pp.

Man, C and Hussain, W (1998). Comparison of frying and performance of refined bleached and deodorised palm olein and coconut oil. J. Food Lipids, 5: 197-210.

Maskan, M (2003). Change in colour and rheological behaviour of sunflower seed oil during frying and after adsorbent treatment of used oil. Euro Food Res. Tech., 218: 20-25.

Mba, O I; Dumont, M J and Ngadi, M (2015). Palm oil: Processing, characterization and utilization in the food industry - A review. Food Biosci., 10: 26-41.

McGill, E A (1980). The chemistry of frying. Bakers Digest, 62(6): 38-42.

Melton, S L; Jafar, S; Sykes, D and Trigiano, M K (1994). Review of stability measurements for frying oils and fried food flavour. J. Amer. Oil Chem Soc., 71(12): 1301-1308.
Nayak, P K; Dash, U; Rayaguru, K and Krishnan, K D (2016). Physico-chemical changes during repeated frying of cooked oil - A review. J. Food Biochem, 40: 371-390.

Pokorny, J (1998). Substrate influence on the frying process. Grasas y Aceites, 49 (3-4): 265-270.

Qin, X (2011). Thermal Desorption Studies of Corn Oil at Frying Temperatures: Thermal Scission Versus Autoxidation. Ph.D thesis, The State University of New Jersey, New Brunswick. 172 pp.

Razali, I; Fauziah, A and Nor Aini, S (1999). Quality of potato chips fried in palm olein and high oleic sunflower oil during batch frying. Proc. of the PORIM International Palm Oil Congress. PORIM, Bangi. p. 99-103.

Rossell, J B (1989). Measurement of rancidity. Rancidity in Foods (Allen, J C and Hamilton, R J eds.). Elsevier Applied Science Publication, London, United Kingdom. p. 27-30.

Rossell, J B (1997). Factors Affecting the Quality of Frying Oils in New Developments in Industrial Frying. Bridgwater: P J Barnes and Associates.

Sebastian, A; Ghazani, S M and Marangoni, A G (2014). Quality and safety of frying oils used in restaurants. Food Res Int., 64: 420-423.

Shaharudin, M R; Wan Mansor, S and Elias, S J (2011). Food quality attributes among Malaysia's fast food customer. Intl. Business and Management, 2(1): 198-208.

Tian, X (2013). Chemical Factors Affecting Degradation Processes of Vegetable Oils During Frying. Ph.D thesis. The State University of New Jersey, New Brunswick. 165 pp.

Tompkins, C and Perkins, E G (1999). The evaluation of frying oils with the Q-anisidine value. J. Amer. Oil Chem. Soc., 76(8): 945-947.

Wai, T W; Saad, B and Lim, PB (2009). Determination of TOTOX value in palm olein using a F1potentiometric analyser. Food Chem., 11: 285-290.

Warner, K and Gupta, M (2003). Frying quality and stability of low and ultra-low-linolenic acid soybean oils. J. Amer. Oil Chem. Soc., 80(3): 275-280. 